\title{
Developmental Changes of Tropoelastin Synthesis by Rat Pulmonary Fibroblasts and Effects of Dexamethasone
}

\author{
AKIHIKO NOGUCHI, KATHRYN FIRSCHING, JONATHAN D. KURSAR, AND \\ RAJKUMAR REDDY \\ Pediatric Research Institute, Cardinal Glennon Children's Hospital, St. Louis University, School of Medicine, \\ St. Louis, Missouri 63104
}

\begin{abstract}
Lung elastin is an important extracellular structural protein and it has been postulated that it plays a regulatory role in alveolar formation. To study the developmental regulation of elastin gene expression, we examined the tropoelastin (TE) production in primary culture of rat pulmonary fibroblasts (RPF). We found that developmental changes in elastin production as assessed by TE synthesis and 3.6-kb TE mRNA levels were similar for RPF and whole tissue except those results from late gestation animals, with peak elastin expression occurring $7 \mathrm{~d}$ postnatally with a decline out to $21 \mathrm{~d}$. At late gestation (20 d), TE mRNA was barely detectable in RPF but clearly detectable TE mRNA in the whole tissue, indicating that there are elastogenic cells other than RPF in the tissue at this age. When TE-producing cells were treated with dexamethasone, there was a dose-dependent stimulation of TE synthesis with the maximum response at $10^{-9}$ to $10^{-7} \mathrm{M}$. Interestingly, dexamethasone had no stimulatory effect on cells from late gestation animals. The developmental window of elastin synthesis in this RPF model between late gestation and $21 \mathrm{~d}$ postnatal seems to correlate with the reported period of secondary alveolar formation, and thus we speculate that RPF elastogenic activity reflects that of the alveolar wall. (Pediatr Res 28: 379-382, 1990)
\end{abstract}

\section{Abbreviations}

RPF, rat pulmonary fibroblast

TE, tropoelastin

SSC, sodium chloride sodium citrate buffer

$\mathrm{RT}$, room temperature

TCA, trichloroacetic acid

Elastin is an important extracellular protein component that forms a resilient fibrous network in the lung. It gives structural compliance to the tissues and may play an important role in the formation of terminal airsacs/alveoli during perinatal stages in various animals, including humans $(1-8)$. This hypothesis is largely based on morphologic observations of elastin deposition in the lung parenchyma and its timely appearance associated with terminal airsac formation.

Elastin is a cross-linked mature form of the protein and proform is secreted as TE, a soluble protein of approximately 72 000-75 $000 \mathrm{~mol}$ wt $(9,10)$. Regulation of TE synthesis is

Received September 20, 1989; accepted May 25, 1990.

Correspondence: Akihiko Noguchi, M.D., Department of Pediatrics, St. Louis University, School of Medicine, 1465 South Grand, St. Louis, MO 63104.

Supported in part by grants from the March of Dimes $(1-1121)$ and the American Lung Association of Eastern Missouri. poorly understood, partly because the regulatory elements of the gene have not been clearly identified. Recent reports indicate that cultured RPF are elastogenic in contrast to lung fibroblasts from larger animals and thus provide a good model for studying lung elastin metabolism (10). However, ontogeny of TE expression in vitro in relation to the original lung tissues has not been described. It is important, therefore, to better characterize the in vitro phenotype so that RPF can be used to investigate the TE gene expression in the lung.

In our study, RPF were isolated from rat tissues of various ages and TE expression was examined at the mRNA and protein levels and compared with the steady-state TE mRNA levels of the original tissues to determine if the TE phenotype is maintained in vitro. We also examined whether dexamethasone modulates TE synthesis of the cultured rat lung cell, inasmuch as glucocorticoids have been shown to stimulate TE synthesis in various other tissues and the effect on the lung might have clinical implications.

\section{MATERIALS AND METHODS}

Cell culture. Timed pregnant rats ( $20 \mathrm{~d}$ gestation) or postnatal rats at 7 or $21 \mathrm{~d}$, and $250 \mathrm{~g}$ body wt adult nonpregnant female rats were killed by intraperitoneal injection of Nembutal $(50 \mathrm{mg} /$ $100 \mathrm{~g}$ body $\mathrm{wt}$ ). Selection of the ages was dependent on the previous report that TE synthesis is low at birth, is at the maximum rate around $7 \mathrm{~d}$, and declines significantly by $21 \mathrm{~d}$ in the rat lung in vivo (11). For gestation and 7-d studies, pups from 2-3 litters were combined, and for 21-d studies, a combination of five pups was used for each sample. Approximately half of the tissue was used for extraction of total RNA and the rest was minced by a tissue chopper (Brinkman Instrument, Westbury, NY) and incubated in RPMI-1640 medium containing collagenase $(0.5 \mathrm{mg} / \mathrm{mL}$, type I, Sigma Chemical Co., St. Louis, MO); pulmonary fibroblasts were isolated by the differential adhesion method (12). The cells were maintained in RPMI-1640 medium supplemented with $10 \%$ FCS and cells of primary culture and subsequent passages were harvested at confluence by trypsin treatment and processed for extraction of total RNA. Cell counts were determined simultaneously using a hematocytometer. TE levels in conditioned media were determined by ELISA.

Steroid treatment. Cells were treated in serum containing medium with $10^{-11}$ to $10^{-5} \mathrm{M}$ concentrations of dexamethasone for $40 \mathrm{~h}$. After the first 24-h treatment period, the medium was changed to RPMI-1640 containing $30 \mathrm{mM} \mathrm{N}$-2-hydroxyethylpiperazine- $N^{\prime}$-2-ethanesulfonic acid, $\mathrm{pH} 7.4$, and the same concentrations of dexamethasone. Medium was collected after the next $16 \mathrm{~h}$ for analysis of TE content by ELISA and total RNA was extracted from the cell layer.

Total protein synthesis. The protein synthesis was estimated by incubating cells in leucine-deficient medium containing $5 \mu \mathrm{L}$ 
of ${ }^{3} \mathrm{H}$-leucine $(60 \mathrm{Ci} / \mathrm{mmol}, 1 \mathrm{mCi} / \mathrm{mL})$ for the last 16 -h period in a culture dish. Medium aliquots of $100 \mu \mathrm{L}$ were precipitated with $200 \mu \mathrm{L}$ of cold $20 \%$ TCA and the pellet was collected by centrifugation. After washing with cold $10 \%$ TCA once, the pellet was dissolved in $100 \mu \mathrm{L}$ of $1 \mathrm{M} \mathrm{NaOH}$ overnight at RT and counted in a scintillation counter (Hewlett-Packard Co., Palo Alto, CA).

ELISA. Medium samples were frozen at $-70^{\circ} \mathrm{C}$, lyophilyzed, and dissolved in $1 / 10$ original volume of PBS containing $0.05 \%$ Tween 20. Ninety-six-well dishes were coated with rat $\alpha$-elastin (40 ng/100 $\mu \mathrm{L} /$ well) purified from rat aortas by the method of Partridge et al. (13). Coated dishes were then incubated overnight at $4^{\circ} \mathrm{C}$ with $0.1 \%$ BSA in PBS (pH 7.4) containing $0.05 \%$ Tween 20. TE samples or rat $\alpha$-elastin standard $(1-256 \mathrm{ng} / 100 \mu \mathrm{L})$ solutions dissolved in the above PBS buffer were reacted with chicken antirat elastin antibody $(1: 2000)$ in glass test tubes at $4^{\circ} \mathrm{C}$ overnight and $100-\mu \mathrm{L}$ aliquots of triplicate samples were transferred to a 96-well dish and incubated for $16 \mathrm{~h}$ at $4^{\circ} \mathrm{C}$. Washed wells were then incubated with peroxidase conjugated goat antichicken antibody for $2 \mathrm{~h}$ at $37^{\circ} \mathrm{C}$. TE content was calculated from the standard curve of the colorimetric reading using Minireader 2 (Dynatech, Alexandria, VA). The background in unconditioned medium containing $10 \%$ FCS was subtracted from each value.

Northern blot analysis. Lung tissues of different ages were separated from the major airways and blood vessels and homogenized in $4 \mathrm{M}$ guanidine isothiocyanate buffer. Cultured cells at confluency were trypsinized and the cell pellet was washed twice with PBS before homogenization in the guanidine isothiocyanate buffer. Extracted total RNA by the standard centrifugation method (14) in the amount of $10 \mu \mathrm{g}$ per lane determined from the spectrophotometric reading at $260 \mathrm{~nm}$ (14) was fractionated by $1 \%$ agarose gel containing $6 \%$ formaldehyde, and gels were stained with ethidium bromide to visualize the $28 \mathrm{~S}$ and $18 \mathrm{~S}$ ribosomal RNA bands to assess recovery and degradation of RNA. Gels were then blotted onto a Nytran filter paper after hydrolysis with a solution containing $50 \mathrm{mM} \mathrm{NaOH}$ and $10 \mathrm{mM}$ $\mathrm{NaCl}$. The dried filter was exposed to UV light for $5 \mathrm{~min}$. Hybridization was performed with nick-translated rat elastin cDNA ${ }^{32} \mathrm{P}-\mathrm{RE} 2$ at $42^{\circ} \mathrm{C}$ in a buffer containing $50 \%$ formamide, $10 \times \mathrm{SSC}, 100 \mathrm{mM}$ Na phosphate, $\mathrm{pH} 6.5,10 \times$ Denhardt's solution (15), and $1 \mathrm{mg} / \mathrm{mL}$ salmon sperm DNA. After washes in $2 \times \mathrm{SSC}$ containing $0.1 \%$ SDS three times at RT, each $5 \mathrm{~min}$, the sheet was washed again three times at $50^{\circ} \mathrm{C}$ in $1 \times \mathrm{SSC}$ containing $0.1 \%$ SDS. The dried filter was exposed to Kodak XAR film at $-70^{\circ} \mathrm{C}$. Later, the same filter was hybridized with nick-translated chicken ${ }^{32} \mathrm{P}-\beta$-actin cDNA (16) in pGEM $4 \mathrm{Z}$ and processed similarly to the above except the second series of washes after the washes at RT were in $2 \times$ SSC containing $0.1 \%$ SDS at $42^{\circ} \mathrm{C}$ four times, 5 min each. $\beta$-Actin probe was used as the control probe to make a comparison with the TE mRNA. Densitometric analysis of the autoradiographs was performed using a model 620 video densitometer (Bio-Rad Laboratories, Richmond, CA)

Materials. Chicken antirat $\alpha$-elastin serum and RE2 cDNA were gifts of Dr. Judith Foster (Syracuse University). The antiserum was further purified by rat $\alpha$-elastin-Sepharose affinity chromatography prepared according to the manufacturer's instructions (Pharmacia Inc., Piscataway, NJ). The plasmid containing RE2 insert was propagated by the standard method in Escherichia coli and purified by agarose gel electrophoresis before nick translation. Restriction enzymes were obtained from Bethesda Research Laboratories (Gaithersburg, MD). ${ }^{32} \mathrm{P}$-nucleotide and ${ }^{3} \mathrm{H}$-leucine was purchased from New England Nuclear (Boston, MA). Nytran filter was from Schuell Inc. (Keene, NJ). All of the other chemicals were purchased from Sigma Chemical Co.

Statistical analysis. Analysis of variance was used to compare the different groups.

\section{RESULTS}

Steady-state TE mRNA in lung tissues and cells. TE mRNA $3.6 \mathrm{~kb}$, was detectable in lung tissues at all ages examined with maximum hybridization signal occurring at $7 \mathrm{~d}$ of age (Fig. 1). The message was slightly larger than the bovine TE mRNA when run side by side (not shown). In cultured RPF, TE mRNA was barely detectable at $20 \mathrm{~d}$ gestation and adult, but the maximum concentration was observed at $7 \mathrm{~d}$ (Fig. 2), similar to the original tissue. There was a significant decline of the message by 21 postnatal $\mathrm{d}$. We used constituitive $\beta$-actin probe as the control probe. When the TE mRNA/ $\beta$-actin mRNA ratio was obtained from the densitometry for tissues and cells, peak was at $7 \mathrm{~d}$ of age for both.

$T E$ in medium. TE protein levels in culture media corresponded generally with RNA levels determined by Northern analysis with maximum levels detected in cells from 7-d animals (Fig. 3). At 21 postnatal d, TE levels returned almost to the background level. TE was at the background level at $20 \mathrm{~d}$ gestation in the rat lung. Although total protein synthesis was highest at $7 \mathrm{~d}$ gestation, the magnitude of difference from the other age groups was less than that of TE synthesis (Fig. 3).

Dexamethasone treatment in culture. Exposure of cultured cells to dexamethasone increased the steady-state TE mRNA (Fig. 4) in a dose-related manner. The response of the adult and 21-d cells was qualitatively similar to that of the 7-d cells. In contrast, there was no stimulation on TE mRNA detected at 20 d gestation with exposure to dexamethasone (data not shown). Densitometric analysis of the autoradiographs of 7-d RPF indicated that there were $35 \pm 10,83 \pm 15,79 \pm 16$, and $52 \pm 10 \%$ $(n=4$ each) increases of the steady-state TE mRNA/ $\beta$-actin
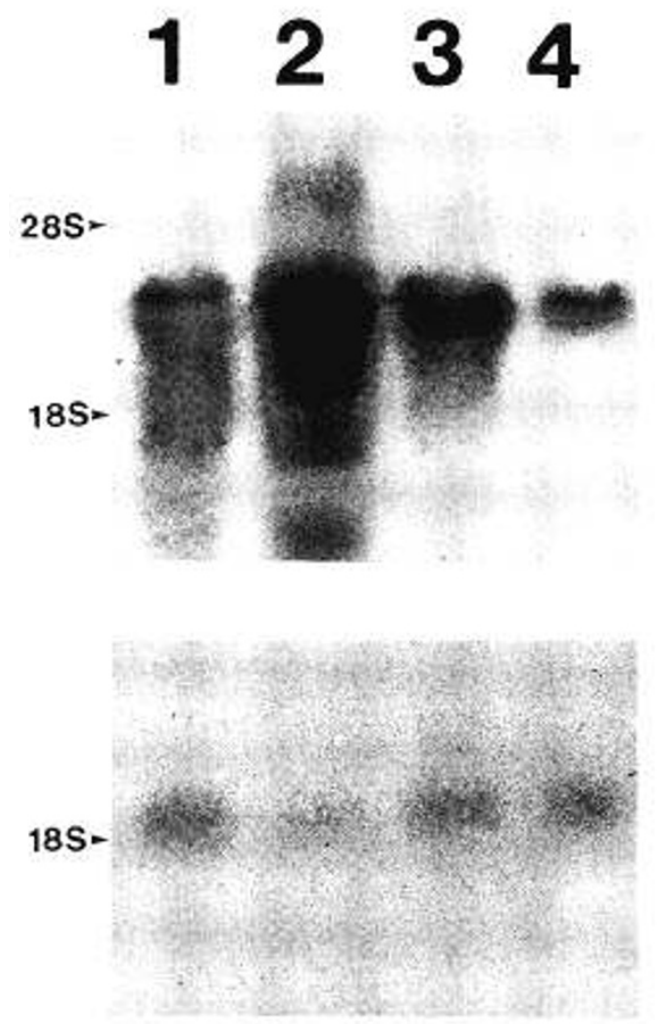

Fig. 1. Northern blot analysis of rat lung tissue. Total RNA was extracted as described in Methods and $10 \mu \mathrm{g}$ per lane were separated and hybridized with rat TE (upper panel) and chicken $\beta$-actin (lower panel) cDNA probes. Representative autoradiograph of the TE message was estimated to be $3.6 \mathrm{~kb}$. The markers on the left side indicate the $28 \mathrm{~S}$ and $18 \mathrm{~S}$ ribosomal RNA positions. $\beta$-actin mRNA was slightly larger than $18 \mathrm{~S}$ and $2.0 \mathrm{~kb}$. Lanes 1, $20 \mathrm{~d}$ gestation; lane 2, 7 postnatal d; lane 3, 21 postnatal d; and lane 4, adult. 

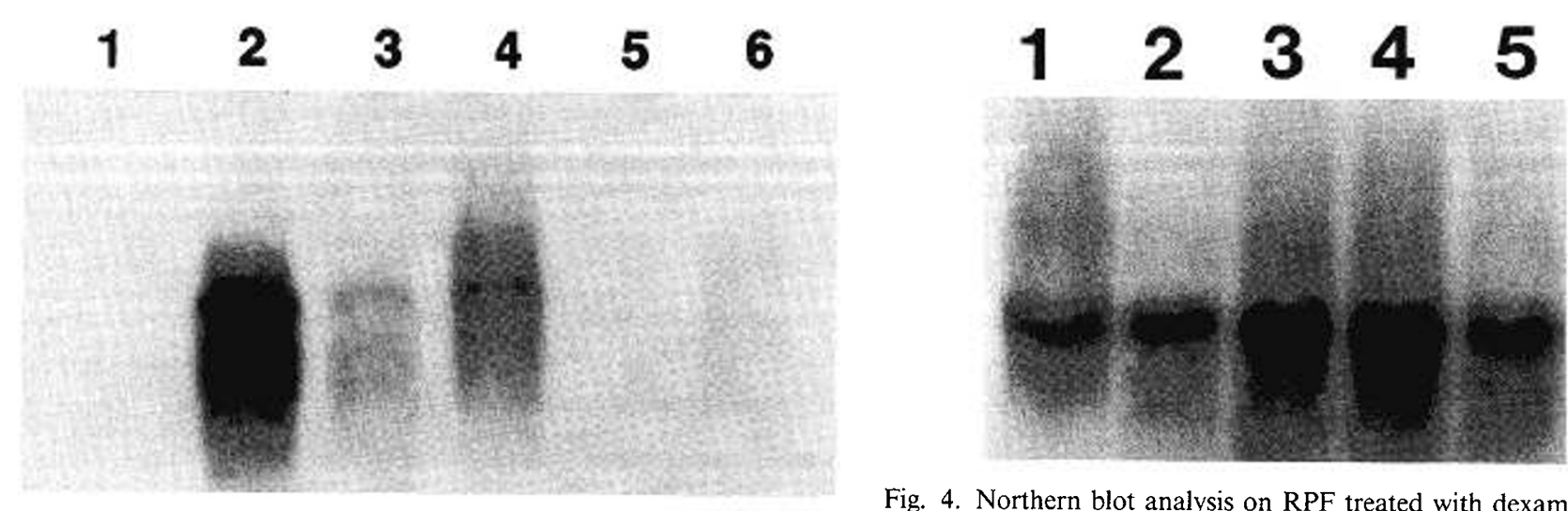

Fig. 4. Northern blot analysis on RPF treated with dexamethasone. Representative autoradiographs of 7-d 1st passage cells. Lane 1, control; lane $2,10^{-11}$; lane $3,10^{-9}$; lane $4,10^{-7}$; and lane $5,10^{-5} \mathrm{M}$ concentrations.

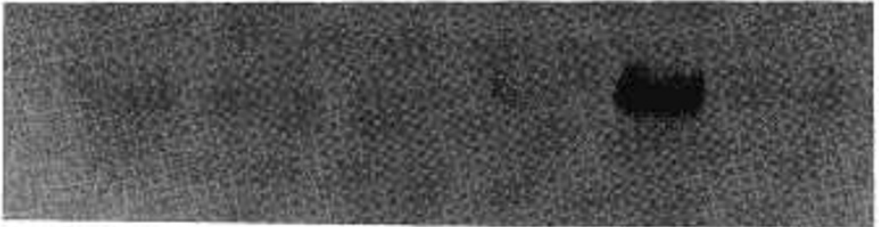

Fig. 2. Representative Northern blot analysis of RPF. Ten $\mu \mathrm{g}$ of total mRNA was placed in each lane and hybridized similarly to the samples in Figure 1. Lane 1, $20 \mathrm{~d}$ gestation; lane 2, 7 postnatal d; lanes 3 and 4, 21 postnatal $\mathrm{d}$ (two different samples) and lanes 5 and 6 , adult (two different samples). Lower panel shows $\beta$-actin mRNA.

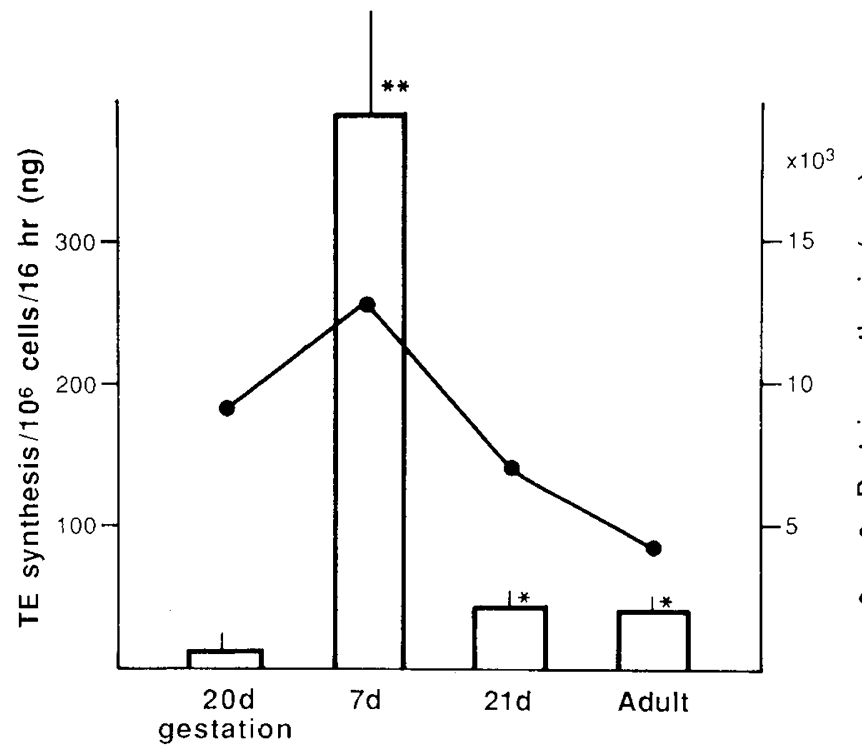

Fig. 3. TE and total protein synthesis by RPF from different ages. Conditioned medium was analyzed for TE concentration by ELISA using rat $\alpha$-elastin as standard. Total protein synthesis was estimated from the ${ }^{3} \mathrm{H}$-TCA precipitable protein in the conditioned medium from a separate dish as described in Methods. $n=4$ for each sample. The bars represent the means and the SEM of four separate samples. *Different from the other three ages, $p<0.001$, ** Different from $20 \mathrm{~d}$ gestation, $p$ $<0.05$ by analysis of variance.

mRNA ratio at $10^{-11}, 10^{-9}, 10^{-7}$, and $10^{-5} \mathrm{M}$ concentrations, respectively, compared with the control, and the values at $10^{-9}$ and $10^{-11} \mathrm{M}$ were significantly higher than the control $(p<$ 0.05 ). When secreted protein TE was examined by ELISA, the dose-response curve was similar to the mRNA changes, with the maximum at $10^{-7}$ to $10^{-9} \mathrm{M}$ with no differences between 7-d

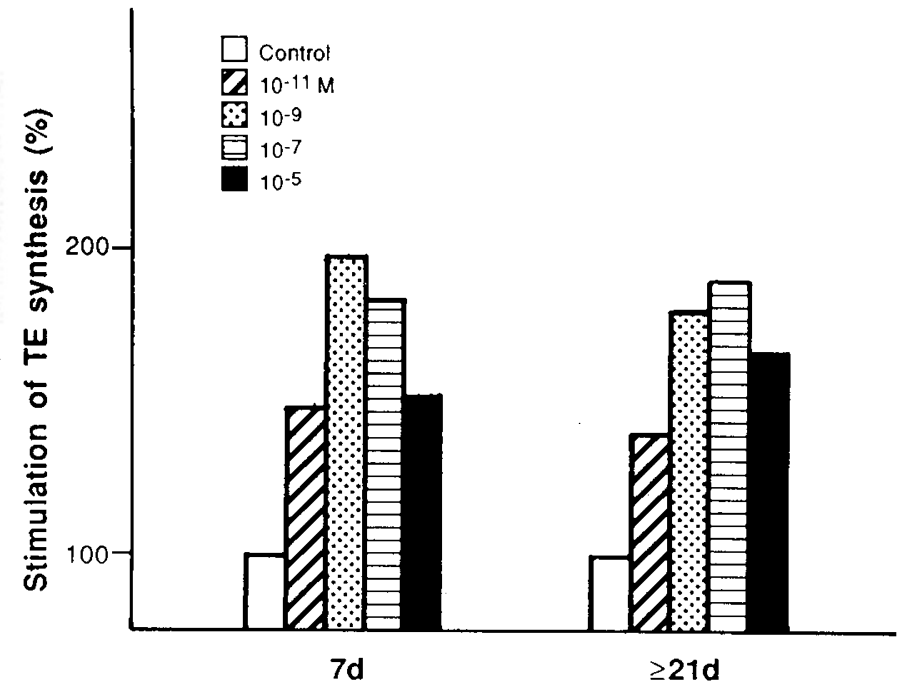

Fig. 5. Dexamethasone stimulation of TE synthesis by RPF. TE was determined at passage 1 cells as in Figure 3 and the conditioned medium after the treatment was analyzed as in Methods. The data were expressed as percentage increase from the untreated control RPF at $100 \%$. For 7 $\mathrm{d}, n=4$ and $\geq 21 \mathrm{~d}, n=6$.

and 21-d or older rats (Fig. 5). Although statistically insignificant, there was a tendency to decrease in the responses at $10^{-5} \mathrm{M}$ in the TE and TE mRNA levels. There were no differences in the ${ }^{3} \mathrm{H}$-leucine incorporation into the TCA-precipitable protein with or without dexamethasone treatment and values for protein synthesis were $95 \pm 11,102 \pm 8,101 \pm 8$, and $93 \pm 7 \%$ of the control protein synthesis at $10^{-11}, 10^{-9}, 10^{-7}, 10^{-5} \mathrm{M}$ concentrations, respectively.

\section{DISCUSSION}

In our study, we have shown that cultured RPF express TE, which is similar to the developmental regulation that has been characterized in the rat lung. Our studies confirm the finding of TE synthesis by neonatal RPF by Campagnone et al. (10) and Powell (17). TE levels determined by ELISA were in good correlation with TE mRNA, indicating transcription as the main mechanism regulating elastin gene expression like other elastogenic cells and tissues. The highest rate of elastin production observed in the 7-d animal is similar to that in the recent report by Powell (17), who examined the TE synthesis in 3rd-passage RPF grown in $2 \%$ FCS. Total TE synthesis by RPF in our study was greater than that observed by Powell and might be related to the different concentrations in the culture media or different generations of passage. The increase in TE synthesis by RPF was a specific, developmentally regulated event that cannot be totally related to the overall increase in the protein synthesis because 
the magnitude of increase in TE production was greater than that for total protein. Signals for rapid decline of TE synthesis postnatally are unclear but developmental windows of the synthetic period have been described in various elastogenic cells/ tissues examined (18-22). Shibahara et al. (22) have shown that in fetal sheep lung tissue, the period of rapid TE synthesis starts in the latter half of gestation, which is similar to bovine lung tissue (23) but distinct from rat lung, where elastin accumulation occurs mainly in the first 2 postnatal wk and becomes quiescent by $3 \mathrm{wk}(11)$. Thus, the developmental increases in TE gene expression in tissue and RPF during the first $7 \mathrm{~d}$ in this study agree with the increase in elastin content in the rat lung tissue reported by Myers et al. (11), implying that RPF among more than 40 different heterogeneous cell types (24) is indeed a contributor to the developmental increase in elastin in the rat lung at $7 \mathrm{~d}$. What are RPF cells? The RPF in our study have been isolated by the standard differential adhesion method, and are identical to those fibroblasts reported by other investigators (25). A high percentage of perinatal RPF in our study contained vesicles that were stained for lipid (not shown) as described previously in lung alveolar fibroblasts in vivo $(2,3,26)$ and in vitro (25); these vesicles are mesenchymal cells that are different from smooth muscle cells. They are also distinct morphologically from other potentially elastogenic endothelial cells, mesothelial cells, or chondrocytes. Nonetheless, RPF cells have not been fully characterized and might be a heterogeneous mixture of fibroblast subtypes. The presence of elastogenic cells different than RPF would explain the detectable TE mRNA in the gestational lung tissue and lack of elastogenic activity in isolated RPF. Presence of desmosine-a specific cross-link of amino acid of elastin-in rat lung tissues of late gestation (27) also supports this contention. Elastin deposition has been seen at smooth muscle sites surrounding airways earlier than the fibroblasts in the rat lung at this age under an electron microscope (26). The ontogeny of elastogenesis by RPF in this study seems to correlate with the period of rapid secondary alveolar septal formation (2) and thus may indeed reflect the elastogenesis of alveolar wall. The relatively narrow developmental window from the lack of TE synthesis in late gestation to the high synthesis at $7 \mathrm{~d}$ postnatal RPF may provide a useful model for examining the TE gene expression in the lung cells in vitro. Brody and associates $(3,8$, 25) classified neonatal RPF into lipid-filled and nonlipid-filled subtypes, suggesting differentiation of fibroblast subtypes during lung maturation. It is not clear whether all or a single subtype of RPF is expressing TE from our study.

Reports on glucocorticoid effects in the perinatal lung in relationship to extracellular matrix protein are scarce.

Schellenberg et al. (27) demonstrated that administration of dexamethasone at $18 \mathrm{~d}$ gestation in rats caused decreased desmosine but normal concentrations of collagen in these animal lungs compared with the control when examined at 10 to 20 postnatal $\mathrm{d}$ (27). The effects on isolated cells at different developmental stages had not been examined to our knowledge. Such information is useful for understanding the potential effects on the perinatal lung mechanics of glucocorticoids, which are widely used in perinatal medicine. Our finding of the stimulatory effects on elastin synthesis is not unique to RPF but has been demonstrated in cell types of diverse animal species (28-30). However, our finding seems contrary to the finding of Foster et al. (31), who, examining the explant culture of the 10-d chick embryo lung, did not detect TE stimulation by glucocorticoids (31). The hormonal response of TE synthesis by the lung cells in the chick embryo thus may not be comparable to that of the early postnatal rat. The lack of stimulation at gestational RPF in rat lung may indicate that the drug does not induce TE expression prematurely in pre-elastin stage cells.
Acknowledgments. The authors thank William J. Keenan, M.D. and Robert P. Mecham, Ph.D. for their critical review of the manuscript.

\section{REFERENCES}

1. Amy RWM, Bowes D, Burri PH, Haines J, Thurlbeck WM 1977 Postnatal growth of the mouse lung. $J$ Anat $24: 131-151$

2. Burri H 1974 The postnatal growth of the rat lung. III. Morphology. Anat Rec 180:77-98

3. Brody J, Vaccaro C 1979 Postnatal formation of alveoli. Interstitial events and physiologic consequences. Fed Proc 38:215-223

4. Loosli CG, Potter EL 1959 Pre and postnatal development of the respiratory portion of the human lung. Am Rev Respir Dis 80:5-20

5. Fukuda Y, Ferrans VJ, Crystal RG 1983 The development of alveolar septa in fetal sheep lung. An ultrastructural and immunohistochemical study. Am J Anat 167:405-439

6. deZabala LE, Weisman D 1984 Prenatal development of the bovine lung. Zbl Vet Med C Anat Histol Embryol 13:1-14

7. Emery JL 1970 The postnatal development of the human lung and its implication for lung pathology. Respiration 27(suppl):41-50

8. Vaccaro C, Brody JS 1978 Ultrastructure of developing alveoli. I. The role of the interstitial fibroblast. Anat Rec 192:467-480

9. Rosenbloom J 1984 Biology of disease. Elastin: relation of protein and gene structure to disease. Lab Invest 51:605-623

10. Campagnone R, Regan J, Rich CB, Miller M, Keene DR, Sakai L, Foster JA 1987 Pulmonary fibroblasts for studying elastin synthesis. Lab Invest 56:224230

11. Myers B, Dubick M, Last JA, Rucker RB 1983 Elastin synthesis during perinatal lung development in the rat. Biochim Biophys Acta 761:17-22

12. Post M, Barsoumian A, Smith BT 1986 The cellular mechanism of glucocorticoid acceleration of fetal lung maturation. J Biol Chem 261:2179-2184

13. Partridge SM, Davis HF, Adair AS 1955 The chemistry of connective tissues. 2. Soluble proteins derived from partial hydrolysis of elastin. Biochem J 61:11-21

14. Davis LG, Dibner MD, Batty JF 1986 Basic Methods in Molecular Biology. Elsevier, New York

15. Denhardt DT 1966 A membrane-technique for detection of complimentary DNA. Biochem Biophys Res Commun 23:641-646

16. Cleveland DW, Lopata MA, McDonald RJ, Cowan NJ, Rutter WJ, Kirschner MW 1980 Number and evolutionary conservation of $\alpha$ - and $\beta$-tubulin and cytoplasmic $\beta$-actin and $\tau$-actin genes using specific cloned cDNA probes. Cell 20:95-105

17. Powell JT 1988 Evidence against lung galaptin being important to the synthesis or organization of the elastic fibril. Biochem $J$ 252:447-452

18. Parks PC, Secrist H, Leeju CW, Mecham RP 1988 Developmental regulation of tropoelastin isoforms. J Biol Chem 263:4416-4423

19. Davidson JM, Hill KE, Alford J 1986 Developmental changes in collagen and elastin biosynthesis in the porcine aorta. Dev Biol 118:103-111

20. Sephel GC, Buckley AB, Davidson JM 1987 Developmental initiation of elastin gene expression by human fetal skin fibroblasts. $J$ Invest Dermatol 88:732735

21. Sephel GC, Davidson JF 1986 Elastin production in human skin fibroblas cultures and its decline with age. J Invest Dermatol 86:279-285

22. Shibahara S, Davidson JM, Smith K, Crystal RG 1981 Modulation of tropoelastin production and elastin messenger ribonucleic acid activity in developing sheep lung. Biochemistry 20:6577-6584

23. Noguchi A, Reddy R, Kursar JD, Parks WC, Mecham RP 1989 Smooth muscle isoactin and elastin in fetal bovine lung. Exp Lung Res 15:537-552

24. Kuhn C 1978 Ultrastructure and cellular function in the distal lung. In: Thurlbeck W (ed) The Lung. Structure, Function and Disease. Williams \& Wilkins, Baltimore, p 1

25. Maksvytis HJ, Harvey J, Vaccaro C, Brody JS 1981 Isolation and characterization of the lipid-containing interstitial cells from the developing rat lung. Lab Invest 45:248-259

26. Collet AJ, Des Biens G 1974 Fine structure of myogenesis and elastogenesis in the developing rat lung. Anat Rec 179:343-360

27. Schellenberg J-C, Liggins GC, Stewart AW 1987 Growth, elastin concentration, and collagen concentration of perinatal rat lung: effects of dexamethasone. Pediatr Res 21:603-607

28. Mecham RP, Morris SL, Levy BD, Wrenn DS 1984 Glucocorticoids stimulate elastin production in differentiated bovine ligament fibroblasts but do not induce elastin synthesis in undifferentiated cells. J Biol Chem 259:1241412418

29. Keely FW, Johnson DJ 1987 Age differences in the effect of hydrocortisone on the synthesis of insoluble elastin in aortic tissue of growing chicks. Connect Tissue Res 16:259-268

30. Eichner R, Rosenbloom J 1979 Collagen and elastin synthesis in the developing chick aorta. Arch Biochem Biophys 198:414-423

31. Foster JA, Rich CB, Curtiss SW, Regan J 1989 Elastin. In: Massaro DI (ed) Lung Biology in Health and Disease, Vol 41. Lung Cell Biology. Marcel Decker, New York, pp 867-905 